\title{
STRATEGI PEMBELAJARAN DAN \\ KEMANDIRIAN TERHADAP HASIL BELAJAR TEKNOLOGI INFORMASI DAN KOMUNIKASI
}

\author{
Ahmad Syafwan dan Abdul Hamid K. \\ SMA Negeri 1 Karang Baru Medan dan PPs Universitas Negeri Medan \\ ahmad.syafwan@gmail.com
}

\begin{abstract}
Abstrak: Penelitian ini bertujuan untuk mengetahui perbedaan hasil belajar siswa yang diajar dengan strategi pembelajaran berbasis internet dan strategi pembelajaran ekspositori, untuk mengetahui perbedaan hasil belajar siswa TIK yang memiliki kemandirian tinggi dan kemandirian rendah, dan untuk mengetahui interaksi antara strategi pembelajaran dan kemandirian dalam mempengaruhi hasil belajar TIK siswa. Metode penelitian menggunakan metode quasi eksperimen dengan desain penelitian faktorial 2x2, sedangkan teknik analisis data menggunakan ANAVA dua jalur pada taraf signifikansi $\alpha=0.05$. Hasil penelitian diperoleh bahwa hasil belajar TIK siswa yang dibelajarkan dengan strategi pembelajaran berbasis internet lebih tinggi dari pada siswa yang dibelajarkan dengan strategi pembelajaran ekspositori, siswa yang memiliki kemandirian tinggi memperoleh hasil belajar TIK yang lebih tinggi daripada siswa yang memiliki kemandirian rendah, dan terdapat interaksi antara strategi pembelajaran dan kemandirian dalam mempengaruhi hasil belajar TIK siswa.
\end{abstract}

Kata Kunci: strategi pembelajaran, kemandirian, hasil belajar teknologi informasi dan komunikasi

\begin{abstract}
This study aims to determine the differences in learning outcomes of students who are taught by internet-based learning strategies and learning strategies expository, to determine differences in student learning outcomes that ICT has a high self-reliance and independence low, and to understand the interaction between learning and self-reliance strategies in influencing ICT learning outcomes students. Method using quasi-experimental research design with a $2 \times 2$ factorial study, while data analysis techniques using ANOVA two lanes at the significance level $\alpha=0: 05$. The results showed that the ICT learning outcomes of students who learned with Internet-based learning strategy is higher than the students who learned with expository teaching strategy, students who have a high gain independence ICT learning outcomes are higher than students who have low self-reliance, and there was an interaction between learning strategies and self-reliance in influencing student learning outcomes ICT.
\end{abstract}

Keywords: learning strategies, self-reliance, learning outcomes of information and communication technology

\section{PENDAHULUAN}

Perkembangan sains dan teknologi yang begitu pesat, menggugah para pendidik untuk dapat merangsang dan melaksanakan pendidikan yang lebih terarah agar dapat menunjang kegiatan siswa sehari-hari dalam proses belajar mengajar. Untuk kepentingan masa depan Indonesia, maka mutu pendidikan harus ditingkatkan. Selanjutnya Soedjadi (1995) menyatakan bahwa untuk menghadapi abad 21 yang diperkirakan akan diwarnai oleh persaingan, bangsa Indonesia mutlak perlu memiliki warga yang bermutu atau berkualitas tinggi. Oleh sebab itu, sebagai subjek dan sekaligus sebagai objek dalam pembangunan, maka manusia Indonesia perlu terus dikembangkan dan ditingkatkan kemampuannya melalui kegiatan pendidikan dan pelatihan. Dengan semakin meningkatnya kualitas sumber daya manusia Indonesia, maka dapat menjadi bekal dalam persaingan global dengan bangsa-bangsa yang lain. Dengan demikian, hanya melalui proses pendidikan yang semakin baik tujuan dari kegiatan pembangunan secara keseluruhan dapat dicapai dengan efektif dan efisien. Hal ini sebagaimana dikemukakan oleh Hamidjojo (dalam Sanjaya, 1982) yaitu pendidikan merupakan suatu usaha terarah ke arah dinamisasi dan pencerdasan masyarakat dengan tujuan mempertinggi daya pikir dan 
daya kerja rakyat melalui bentuk dan prosedur kooperatif yang berswadaya.

Meskipun telah banyak upaya yang dilakukan oleh pemerintah, namun dalam kenyataannya mutu pendidikan masih tetap rendah. Gambaran umum memperlihatkan bahwa masih rendahnya hasil belajar siswa Sekolah Menengah Atas (SMA) khususnya di SMA Negeri 1 Karang Baru yang telah mempunyai sarana lengkap berupa laboraturium komputer sejak tahun 2008 pada mata pelajaran TIK, baru melengkapi sarana komputer bagi siswa-siswi, sehingga siswa dituntut dapat memanfaatkan internet sebagai sumber belajar dengan memiliki cara belajar dan sikap mandiri yang baik dalam menunjang kegiatan pembelajaran semaksimal mungkin, sehingga mampu menetralisir kelemahan dan kekurangan dalam nilai yang diperolehnya.

Dalam proses belajar mengajar mata pelajaran TIK, guru mempersiapkan sebuah Compack Disk $(C D)$ yang di dalamnya berisi materi-materi yang berhubungan dengan pembelajaran TIK. Materi-materi tersebut di download dari beberapa situs komputer di internet, dan selanjutnya CD tersebut dijadikan referensi dalam menjalani proses belajar mengajar, dengan tujuan agar siswa dapat mengulang dan mempelajari materimateri tersebut di rumah, mendalami dengan mengakses kembali situs-situs tersebut langsung dari internet atau mengerjakan tugas yang diberikan guru mata pelajaran TIK baik praktek, presentasi maupun men-download kelengkapan tugas melalui internet pada situssitus sesuai dengan instruksi guru. Namun pada kenyatannya perolehan hasil belajar mata pelajaran TIK masih tetap rendah. Berdasarkan hasil pengamatan di dalam kelas pada saat pembelajaran, siswa cenderung tergantung pada jawaban yang diberikan oleh guru mata pelajaran TIK baik dalam menyelesaikan tugas yang diberikan maupun dalam mendalami materi yang diberikan. Siswa tidak memiliki sikap untuk mencari sumber belajarnya secara mandiri terutama dalam memanfaatkan internet yang jelas tersedia di sekolah dengan sangat baik. Selain itu, kebanyakan guru mengajar dengan menggunakan satu metode saja atau guru yang mendominasi proses belajar mengajar. Guru kurang memvariasikan model atau strategi pembelajaran dalam proses belajar mengajar. Ini dapat dilihat dari hasil perolehan siswa dalam belajar melalui evaluasi akhir bahwa hasil belajar yang diperoleh siswa masih relatif paling rendah dibandingkan dengan mata pelajaran lainnya. Dari nilai raport siswa semester IV pada mata pelajaran TIK kelas XI jurusan IPA SMA Negeri 1 Karang Baru tahun ajaran 2009/2010, diperoleh data bahwa nilai rata-rata hasil belajar siswa pada mata pelajaran TIK belum memuaskan yaitu kurang dari 7,00

Rendahnya hasil belajar yang didapatkan siswa tersebut dapat disebabkan oleh beberapa faktor, salah satu faktor yang diduga adalah cara belajar dalam memanfaatkan internet sebagai sumber belajar yang diterapkan siswa kurang baik, karena siswa menerapkan sistem belajar pasif seperti jarang bertanya, jarang menjawab pertanyaan guru, jarang mencatat, kurang memanfaatkan sumber belajar dengan sangat baik, jarang mengulang materi pelajaran di rumah, jarang berdiskusi kelompok, dan lain sebagainya.

Banyak faktor yang menjadi penyebab rendahnya dan kurangnya pemahaman peserta didik tentang konsep belajar, salah satu di antaranya adalah strategi pembelajaran yang digunakan oleh pengajar. Berkaitan dengan praktik pembelajaran TIK di sekolah, guru sangat berperan dalam menentukan berhasil tidaknya tujuan pembelajaran. Idealnya dalam merancang kegiatan pembelajaran, guru harus dapat melatih siswa untuk bertanya, mengamati, menyelidiki, membaca, mencari, dan menemukan jawaban atas pertanyaan baik yang diajukan oleh guru maupun yang mereka ajukan sendiri. Pengetahuan yang disampaikan kepada siswa bukan hanya dalam bentuk produk, tetapi juga dalam bentuk proses, artinya dalam proses mengajar, pengenalan, pemahaman, pelatihan metode, dan penalaran siswa, merupakan hal yang penting untuk diajarkan (Atmadi dkk, 2000).

$$
\text { Selain pemilihan strategi }
$$

pembelajaran yang tepat, perolehan hasil belajar dipengaruhi oleh kemampuan guru dalam mengenal dan memahami karakteristik siswa. Reigeluth (1983), mengungkapkan bahwa hasil pembelajaran berhubungan dengan interaksi antara strategi pembelajaran dan kondisi pengajaran, yang di dalamnya termasuk karakteristik siswa. Selanjutnya Dick \& Carey (2005) juga mengungkapkan hal yang sama dengan menyatakan bahwa guru hendaknya mampu untuk mengenal dan mengetahui karakteristik siswa, sebab pemahaman yang baik terhadap keberhasilan proses belajar siswa apabila guru telah 
mengetahui karakteristik siswanya maka selanjutnya guru dapat menyesuaikannya dengan strategi pembelajaran yang akan digunakan. Joyce \& Marsha (1986) mengemukakan bahwa para pakar pembelajaran seperti Piaget (1970), Meril (1977), dan Romiszowski (1981) menyebutkan bahwa karakteristik yang bersumber dari siswa penting untuk diperhatikan dan sangat menentukan kualitas pembelajaran dan sangat dominan dalam keberhasilan proses belajar siswa.

Salah satu karakteristik siswa adalah kemandirian. Dalam suatu proses belajar mengajar, seorang guru hendaknya mampu mengetahui dan memahami kemandirian yang dimiliki oleh seorang siswa, sebab dengan mengetahui kemandirian siswa, seorang guru dapat menyesuaikan, menyusun dan membuat materi ajar yang relevan untuk membantu dan mengarahkan kesiapan siswa untuk menerima materi pelajaran. Piaget (1977) menyatakan bahwa tujuan pembelajaran TIK akan dapat dicapai dengan baik apabila siswa telah memiliki kemandirian yang memadai. Selanjutnya, Antonius (2000), kemandirian siswa adalah cerminan dan gambaran tingkah laku atau prilaku yang relatif tetap dalam diri seseorang dalam menerima, memikirkan, dan mewujudkan pengetahuan dan keterampilan guna menghasilkan sesuatu demi pemenuhan kebutuhan hidupnya. Mu'tadin (2000), mengemukakan kemandirian adalah suatu sikap individu yang diperoleh secara kumulatif selama perkembangan, individu akan terus belajar untuk bersikap mandiri dalam menghadapi berbagai situasi lingkungan, sehingga individu pada akhirnya akan mampu berfikir dan bertindak sendiri dengan kemandiriannya, seseorang dapat memilih jalan hidupnya untuk dapat berkembang dengan lebih mantap.

Berdasarkan uraian di atas, dapat dipahami bahwa pemilihan strategi pembelajaran TIK yang tepat, hendaknya disesuaikan dengan kemandirian siswa, sehingga siswa dapat memahami sejauh mana siswa tersebut telah menguasai dan memahami mata pelajaran yang dihadapinya. Kemandirian peserta didik adalah salah satu komponen yang harus diperhatikan dengan seksama karena kemampuan seorang guru dalam mengidentifikasi kemandirian yang dimiliki peserta didiknya akan membantu dalam menentukan strategi teori belajar, dan media belajar yang cocok untuk digunakan.
Hal ini perlu dilakukan agar pelajaran yang disampaikan dapat menarik perhatian peserta didik dan setiap jam pelajaran tidak terasa membosankan, tetap mendapat perhatian yang utuh dari siswa yang mengikuti proses pembelajaran.

Kitao (dalam Siahaan, 2002), menjelaskan bahwa sebagai sebuah jaringan global, internet menjadikan batas ruang dan waktu semakin menipis. Kondisi dasar teknologi internet dan aplikasi yang berjalan diatasnya ini memungkinkan untuk dimanfaatkan dalam proses pendidikan, terutama sebagai sarana pembawa konten pendidikan (education delivery medium). Dengan demikian, lokasi dan waktu belajar yang selama ini sering menjadi "penjara" bagi peserta didik akan hilang dan memberikan keleluasaan dan keluwesan bagi mereka untuk mendapatkan sumber materi ajar di mana pun dan kapan pun. Lebih lanjut dijelaskan bahwa pemanfaatan fasilitas internet sebagai sumber belajar dan sarana pembelajaran dapat diimplementasikan dalam 4 (empat) kegiatan

Miarso (2005) mengemukakan peranan internet di dalam pendidikan dapat dilihat dari dua sudut pandang yaitu: (a) peserta didik, di mana dengan internet dimungkinkan berkembangnya kebebasan berfikir dan eksplorasi peserta didik terhadap materi belajar. Peserta didik dapat mengakses bahanbahan belajar setiap saat dan berulang-ulang, atau bahkan menyelesaikan pemecahan masalah melalui berbagai sumber dan literatur. Peserta didik juga dapat berkomunikasi dengan guru setiap saat, dengan demikian peserta didik dapat lebih memantapkan penguasaannya terhadap materi pembelajaran, dan (b) pendidik/pengajar, di mana dengan internet beberapa manfaat yang dapat diperoleh oleh pengajar dalam kaitan pembelajaran di kelas dan luar kelas. Dalam hal ini, manfaat yang dapat diperoleh oleh guru atau pengajar dalam kaitan pembelajaran antara lain : (a) guru dapat lebih mudah melakukan pemutakhiran bahan-bahan belajar yang menjadi tanggung jawabnya sesuai dengan tuntutan perkembangan keilmuan yang terjadi, (b) mengembangkan diri atau melakukan penelitian guna meningkatnya wawasan keilmuan karena waktu dan peluang ralatif banyak, dan (c) melakukan pengecekan tugas-tugas yang diberikan oleh guru terbilang lebih mudah, hingga pengontrolan aktifitas penggunaan komputer dapat dilakukan. Pola pembelajaran menggunakan internet seperti 
ini dapat mengubah peranan guru, yang semula lebih banyak bertindak sebagai satu sumber belajar utama, menjadi pengelola kegiatan belajar yang memberi kesempatan dan bimbingan kepada anak didiknya untuk mencari dan menggunakan sumber belajar lain.

Strategi pembelajaran ekspositori adalah strategi pembelajaran yang menekankan kepada proses penyampaian materi secara verbal dari seorang guru kepada sekelompok siswa dengan maksud agar siswa dapat menguasai materi pembelajaran secara optimal. Killen (dalam Sanjaya, 2006) menamakan strategi ekspositori ini dengan istilah strategi pembelajaran langsung (direct insruction), karena dalam strategi ini materi pembelajaran disampaikan langsung oleh guru, dan siswa tidak dituntut untuk menemukan sendiri materi itu, dan materi pembelajaran seakan-akan sudah jadi atau telah dipersiapkan oleh guru.

Kemandirian merupakan salah satu aspek kepribadian yang sangat penting bagi individu. Seseorang dalam menjalani kehidupan ini tidak pernah lepas dari cobaan dan tantangan. Individu yang memiliki kemandirian tinggi relatif mampu menghadapi segala permasalahan karena individu yang mandiri tidak tergantung pada orang lain, selalu berusaha menghadapi dan memecahkan masalah yang ada. Kemandirian merupakan kemampuan individu untuk bertingkah laku sesuai keinginannya. Perkembangan kemandirian merupakan bagian penting untuk dapat menjadi otonom dalam masa remaja. Menurut Steinberg (2002:290), kemandirian merupakan kemampuan individu untuk bertingkah laku secara seorang diri.

Kemandirian belajar adalah aktivitas belajar yang di dorong oleh kemauan sendiri, pilihan sendiri dan tanggung jawab sendiri tanpa bantuan orang lain serta mampu mempertanggung jawabkan tindakannya. Siswa dikatakan telah mampu belajar secara mandiri apabila ia telah mampu melakukan tugas belajar tanpa ketergantungan dengan orang lain. Ciri-ciri pokok siswa mampu mandiri dalam belajar dapat dilihat dari bagaimana ia memulai belajarnya, mengatur waktu dalam belajar sendiri melakukan belajar dengan cara dan teknik sesuai dengan kemampuan sendiri serta mampu mengetahui kekurangan diri sendiri. Sebagai syarat agar siswa dapat belajar mandiri, siswa tersebut harus memiliki dan melatih metode belajar yang baik, sehingga sejak awal dari pemberian tugas belajar, harus sudah timbul dalam jiwa dan pikiran anak untuk menata kegiatan belajar sendiri berdasarkan metodologi belajar yang baik dan pada tahapan-tahapan dalam proses belajar tersebut tidak harus "diperintah". Siswa mengetahui arah tujuan serta langkah yang harus diperbuatnya dalam menyelesaikan tugas yang dihadapkan kepadanya. Siswa memiliki kemahiran dalam menyelesaikan tugas belajarnya dan mampu mengimplementasikan pengetahuan yang diperolehnya tersebut.

Adapun yang menjadi tujuan penelitian ini adalah untuk: (1) Mengetahui apakah hasil belajar TIK siswa yang dibelajarkan dengan strategi pembelajaran berbasis internet lebih tinggi dari pada siswa yang dibelajarkan dengan strategi pembelajaran ekspositori; (2) Mengetahui apakah hasil belajar TIK siswa yang mempunyai kemandirian tinggi memperoleh hasil belajar TIK yang lebih tinggi dari pada siswa yang mempunyai kemandirian rendah; dan (3) Mengetahui apakah terdapat interaksi antara strategi pembelajaran dan kemandirian dalam mempengaruhi hasil belajar TIK siswa.

\section{METODE PENELITIAN}

Penelitian ini dilaksanakan di SMA Negeri 1 Karang Baru, siswa kelas XI yang menerima mata pelajaran TIK. Populasi dalam penelitian ini adalah seluruh siswa kelas XI yang berjumlah 160 orang yang tersebar dalam 4 kelas, di mana di antara kelas pada sekolah tidak terdapat kelas unggulan, maka yang menjadi populasi terjangkau dalam penelitian ini sebanyak 4 kelas. Teknik pengambilan sampel dalam penelitian ini dilakukan melalui pengambilan sampel cluster random sampling, yaitu mengundi 4 kelas yang ada untuk mendapatkan 2 kelas sebagai sampel penelitian.

Penelitian ini menggunakan metode eksperimen semu dengan desain faktorial $2 \mathrm{x}$ 2 , sebab menggunakan kelas yang sudah terbentuk sebelumnya, dan melalui desain ini akan dibandingkan pengaruh perlakuan pembelajaran dengan menggunakan berbasis internet dan ekspositori terhadap hasil belajar TIK ditinjau dari karakteristik kemandirian siswa. Pembelajaran dengan berbasis internet dan ekspositori sebagai variabel bebas, dan kemandirian tinggi dan rendah sebagai variabel moderator dan perolehan hasil belajar TIK sebagai variabel terikat. 
Teknik analisis data yang digunakan dalam penelitian ini adalah teknik statistik deskriptif dan inferensial. Teknik statistik deskriptif digunakan untuk mendeskripsikan data, antara lain nilai rata-rata (mean), median, standard deviasi (SD) dan kecenderungan data. Teknik statistik inferensial digunakan untuk menguji hipotesis penelitian, dengan teknik analisis varians Anava dua jalur (desain factorial $2 \times 2$ ) dengan taraf signifikan $5 \%$ atau 0,05 . Sebelum Anava dua jalur dilakukan, terlebih dahulu ditentukan persyaratan analisis, yaitu persyaratan normalitas dan homogenitas. Uji persyaratan normalitas menggunakan uji Liliefors, dan uji persyaratan homogenitas menggunakan uji Bartlett dan Uji Fisher. Bila uji Anava dua jalur signifikan, maka dilakukan uji lanjut menggunakan Uji Scheffe, karena diperkirakan jumlah sample dari masing-masing sel dalam rancangan penelitian tidak sama, akan tetapi bila ditemukan jumlah peserta untuk setiap sel sama maka akan dilakukan uji lanjut menggunakan Uji Tuckey.

\section{HASIL DAN PEMBAHASAN \\ Hasil}

Berdasarkan data skor tes hasil belajar siswa, langkah berikutnya adalah menghitung total skor dan rata-rata skor tiap kelompok perlakuan menurut Tabel anava, yang selanjutnya dapat digunakan sebagai dasar keputusan statistik untuk pengujian hipotesis, seperti pada Tabel 1 .

Tabel 1. Tabel Hasil Statistik Deskriptif

\begin{tabular}{|c|c|c|c|c|c|}
\hline $\begin{array}{ll}\mathrm{SK} & \mathrm{SP} \\
\end{array}$ & Berbasis Internet & & kspositori & & Total \\
\hline Tinggi & $\begin{aligned} \frac{\mathrm{N}}{\mathrm{X}} & =23 \\
\mathrm{Sd} & =23,31 \\
& =1,99\end{aligned}$ & $\frac{\mathrm{N}}{\mathrm{X}}$ & $\begin{array}{l}=21 \\
=18,14 \\
=1,63\end{array}$ & $\begin{array}{l}\frac{N}{X} \\
S c\end{array}$ & $\begin{array}{l}=44 \\
=20,86 \\
=3,62\end{array}$ \\
\hline Rendah & $\begin{aligned} \mathrm{N} & =17 \\
\overline{\mathrm{X}} & =14,53 \\
\mathrm{Sd} & =2,23\end{aligned}$ & $\begin{array}{l}\frac{N}{X} \\
S d\end{array}$ & $\begin{array}{l}=19 \\
=16,47 \\
=2,54\end{array}$ & $\frac{\mathrm{N}}{\mathrm{X}}$ & $\begin{array}{l}=39 \\
=15,50 \\
=4,77\end{array}$ \\
\hline Total & $\begin{aligned} \mathrm{N} & =40 \\
\overline{\mathrm{X}} & =18,92 \\
\mathrm{Sd} & =4,22\end{aligned}$ & $\begin{array}{l}\frac{\mathrm{N}}{\mathrm{X}} \\
\mathrm{Sd}\end{array}$ & $\begin{array}{l}=40 \\
=17,31 \\
=4,17\end{array}$ & $\begin{array}{l}\frac{N}{X} \\
S d\end{array}$ & $\begin{array}{l}=80 \\
=36,23 \\
=8,39\end{array}$ \\
\hline
\end{tabular}

Uji persyaratan normalitas dan homogenitas ternyata terpenuhi untuk menggunakan Anava, maka selanjutnya dilakukan Uji Hipotesis. Secara keseluruhan hasil Anava untuk pengujian hipotesis dapat dilihat pada Tabel 2 berikut.

Tabel 2. Rangkuman Hasil Anava Secara Keseluruhan Terhadap Hasil Belajar TIK

\begin{tabular}{|l|r|l|r|l|l|}
\hline \multicolumn{1}{|c|}{ Sumber Variansi } & JK & \multicolumn{1}{c|}{$\mathrm{dk}$} & \multicolumn{1}{c|}{ RJK } & $\mathrm{F}_{\text {hitung }}$ & $\mathrm{F}_{\text {tabel }}$ \\
\hline Sikap Kemandirian Siswa & 553,11 & 1 & 553,11 & 95,52 & 3,12 \\
Strategi Pembelajaran & 99,01 & 1 & 99,01 & 17,11 & 3,12 \\
Interaksi Antara Strategi Pembelajaran & 227,35 & 1 & 227,35 & 39,27 & 3,12 \\
dan Sikap Kemandirian Siswa & & & & & \\
Dalam Kelompok (Kekeliruan) & 440,41 & 76 & 5,79 & & \\
\hline Total & 1319,88 & 79 & & & \\
\hline
\end{tabular}

Hasil belajar TIK siswa yang diajarkan strategi pembelajaran berbasis Internet lebih tinggi daripada strategi pembelajaran Ekspositori. adalah :

Adapun hipotesis statistik yang diuji

$$
\begin{aligned}
& \text { Ho }: \mu \mathrm{A} 1=\mu \mathrm{A} 2 \\
& \mathrm{Ha}: \mu \mathrm{A} 1>\mu \mathrm{A} 2
\end{aligned}
$$

Rata-rata nilai hasil belajar TIK kelompok strategi pembelajaran berbasis Internet sebesar 19,58, dan kelompok strategi pembelajaran ekspositori sebesar 17,88. Selanjutnya, berdasarkan hasil pengujian hipotesis pada Tabel 19 diperoleh $F_{\text {hitung }}$ sebesar 17,11. Sementara nilai kritik $F_{\text {table }}$ dengan $\mathrm{dk}=(1,76)$ dan $\propto=5 \%$ sebesar 3,12. 
Hasil ini menunjukkan bahwa $F_{\text {hitung }}=17,11>$ $F_{\text {table }}=3,12$ sehingga Hipotesis Nol (Ho) ditolak dan hipotesis alternatif (Ha) diterima. Dengan demikian, hipotesis penelitian yang menyatakan bahwa hasil belajar TIK siswa yang dibelajarkan dengan strategi pembelajaran Berbasis Internet lebih tinggi dari pada siswa yang diajarkan dengan strategi pembelajaran ekspositori teruji kebenarannya.

Siswa yang memiliki sikap kemandirian tinggi memperoleh hasil belajar TIK yang lebih tinggi daripada siswa yang memiliki sikap kemandirian rendah.

Adapun hipotesis statistik yang diuji adalah :

Ho $: \mu \mathrm{B} 1=\mu \mathrm{B} 2$

$\mathrm{Ha}: \mu \mathrm{B} 1>\mu \mathrm{B} 2$

Rata-rata nilai hasil belajar TIK kelompok siswa yang memiliki sikap kemandirian tinggi sebesar 20,84, dan kelompok strategi pembelajaran ekspositori sebesar 15,56. Selanjutnya, berdasarkan hasil pengujian hipotesis pada Tabel 19, diperoleh $\mathrm{F}_{\text {hitung }}=95,52$ dan nilai kritik $\mathrm{F}_{\text {tabel }}$ dengan $\mathrm{dk}$ $=(1,76)$ dan $\propto=5 \%$ adalah 3,12. Hasil ini menunjukkan bahwa $\mathrm{F}_{\text {hitung }}=95,52>\mathrm{F}_{\text {table. }}=$ 3,12 sehingga Hipotesis Nol (Ho) ditolak dan hipotesis alternatif ( $\mathrm{Ha}$ ) diterima. Dengan demikian, hipotesis penelitian yang menyatakan bahwa siswa yang memiliki sikap kemandirian tinggi memperoleh hasil belajar TIK yang lebih tinggi dari pada siswa yang memiliki Sikap Kemandirian rendah teruji kebenarannya.

Interaksi antara strategi pembelajaran dan sikap kemandirian siswa dalam mempengaruhi hasil belajar TIK

Adapun hipotesis statistik yang diuji adalah :
Ho : $\mathrm{A}><\mathrm{B}=0$
Ha : $\mathrm{A}><\mathrm{B} \neq 0$
Rata-rata nila

Rata-rata nilai hasil belajar TIK kelompok siswa dengan sikap kemandirian tinggi yang dibelajarkan dengan strategi pembelajaran berbasis Internet sebesar 23,31, dan rata-rata nilai hasil belajar TIK kelompok siswa dengan sikap kemandirian tinggi yang dibelajarkan dengan strategi pembelajaran ekspositori sebesar 14,53 . Selanjutnya, ratarata nilai hasil belajar TIK kelompok siswa dengan sikap kemandirian rendah yang dibelajarkan dengan strategi pembelajaran berbasis Internet sebesar 18,14, dan rata-rata nilai hasil belajar TIK kelompok siswa dengan sikap kemandirian rendah dibelajarkan dengan strategi pembelajaran berbasis Internet sebesar 16,47 .

Berdasarkan hasil pengujian hipotesis di atas diperoleh $\mathrm{F}$ hitung $=39,27$ dan nilai kritik $\mathrm{F}_{\text {table }}$ dengan $\mathrm{dk}=(1,76)$ dan $\propto=5 \%$ adalah 3,12. Hasil ini menunjukkan bahwa $\mathrm{F}_{\text {hitung }}=$ $39,27>\mathrm{F}_{\text {table. }}=3,12$ sehingga Hipotesis Nol (Ho) ditolak dan hipotesis alternatif (Ha) diterima. Dengan demikian, hipotesis penelitian yang menyatakan bahwa terdapat interaksi antara strategi pembelajaran dan sikap kemandirian dalam memberikan pengaruh terhadap hasil belajar TIK teruji kebenarannya.

Karena ada interaksi antara strategi pembelajaran dan sikap kemandirian dalam mempengaruhi hasil belajar TIK, maka perlu dilakukan uji lanjutan (post hoc test), untuk mengetahui rata-rata hasil belajar sampel mana yang berbeda. Untuk melihat bentuk interaksi antara strategi pembelajaran dan Sikap Kemandirian dalam mempengaruhi hasil belajar TIK, dilakukan uji lanjut dengan menggunakan uji Scheffe'.Ringkasan hasil uji Scheffe' dapat dilihat pada Tabel 3.

Tabel 3. Ringkasan Hasil Perhitungan Uji Scheffe'

\begin{tabular}{|c|r|r|r|}
\hline \multirow{2}{*}{$\begin{array}{c}\text { Skor Kelompok } \\
\text { yang dibandingkan }\end{array}$} & \multirow{2}{*}{$\mathrm{F}_{\text {hitung }}$} & \multicolumn{2}{|c|}{$\mathrm{F}_{\text {tabel }}$} \\
\cline { 3 - 4 } & & $\alpha=0,05$ & $\alpha=0,01$ \\
\hline$\mu \mathrm{A}_{1} \mathrm{~B}_{1}$ dengan $\mu \mathrm{A}_{2} \mathrm{~B}_{1}$ & 13,31 & 2,73 & 4,05 \\
\hline$\mu \mathrm{A}_{1} \mathrm{~B}_{1}$ dengan $\mu \mathrm{A}_{1} \mathrm{~B}_{2}$ & 11,41 & 2,73 & 4,05 \\
\hline$\mu \mathrm{A}_{1} \mathrm{~B}_{1}$ dengan $\mu \mathrm{A}_{2} \mathrm{~B}_{2}$ & 43,97 & 2,73 & 4,05 \\
\hline$\mu{ }_{2} \mathrm{~B}_{1}$ dengan $\mu \mathrm{A}_{2} \mathrm{~B}_{2}$ & 9,15 & 2,73 & 4,05 \\
\hline$\mu \mathrm{A}_{2} \mathrm{~B}_{1}$ dengan $\mu \mathrm{A}_{1} \mathrm{~B}_{2}$ & 26,48 & 2,73 & 4,05 \\
\hline$\mu \mathrm{A}_{2} \mathrm{~B}_{2}$ dengan $\mu \mathrm{A}_{1} \mathrm{~B}_{2}$ & 4,58 & 2,73 & 4,05 \\
\hline
\end{tabular}


Kriteria penerimaan jika : $\mathbf{F}$ hitung $>\mathbf{F}$ table , maka teruji secara signifikan.

Berdasarkan hasil uji Scheffe' pada Tabel 3 di atas dapat dilihat bahwa terdapat 6 (enam) pasang hipotesis statistik, yakni :

a. Dari hasil perhitungan dengan menggunakan uji Scheffe' pada tabel di atas menunjukkan $F_{\text {hitung }}=13,31>\mathrm{F}_{\text {tabel }}=$ 2,73, sehingga memberikan keputusan menolak hipotesis nol (Ho), dan hipotesis alternatif (Ha) diterima. Dengan demikian, hipotesis penelitian yang menyatakan bahwa hasil belajar TIK siswa jika diajar menggunakan strategi pembelajaran berbasis Internet lebih tinggi dibandingkan dengan strategi pembelajaran ekspositori untuk siswa yang memiliki sikap kemandirian tinggi teruji kebenarannya.

b. Dari hasil perhitungan dengan menggunakan uji Scheffe' pada tabel di atas menunjukkan $\mathrm{F}_{\text {hitung }}=11,41>\mathrm{F}_{\text {tabel }}=$ 2,73, sehingga memberikan keputusan menolak hipotesis nol (Ho), dan hipotesis alternatif (Ha) diterima. Dengan demikian, hipotesis penelitian yang menyatakan bahwa siswa yang memiliki sikap kemandirian tinggi memperoleh hasil belajar TIK yang lebih tinggi dari pada siswa yang memiliki sikap kemandirian rendah jika diajar menggunakan strategi pembelajaran berbasis Internet teruji kebenarannya.

c. Dari hasil perhitungan dengan menggunakan uji Scheffe' pada tabel di atas menunjukkan $\mathrm{F}_{\text {hitung }}=43,97>\mathrm{F}_{\text {tabel }}=$ 2,73, sehingga memberikan keputusan menolak hipotesis nol (Ho), dan hipotesis alternatif (Ha) diterima. Dengan demikian, hipotesis penelitian yang menyatakan bahwa hasil belajar TIK siswa dengan Sikap Kemandirian tinggi jika diajar menggunakan strategi pembelajaran berbasis Internet lebih tinggi dibandingkan dengan siswa yang memiliki sikap kemandirian rendah diajar menggunakan strategi pembelajaran ekspositori teruji kebenarannya. d. Dari hasil perhitungan dengan menggunakan uji Scheffe' pada tabel di atas menunjukkan $\mathrm{F}_{\text {hitung }}=9,15>\mathrm{F}$ tabel $=$ 2,73, sehingga memberikan keputusan menolak hipotesis nol (Ho), dan hipotesis alternatif (Ha) diterima. Dengan demikian, hipotesis penelitian yang menyatakan bahwa siswa dengan sikap kemandirian rendah jika dibelajarkan dengan menggunakan strategi pembelajaran ekspositori memperoleh hasil belajar TIK yang lebih tinggi dibandingkan dengan siswa yang memiliki sikap kemandirian tinggi teruji kebenarannya.

e. Dari hasil perhitungan dengan menggunakan uji Scheffe' pada tabel di atas menunjukkan $F_{\text {hitung }}=26,48>F_{\text {tabel }}=$ 2,73, sehingga memberikan keputusan menolak hipotesis nol (Ho), dan hipotesis alternatif (Ha) diterima. Dengan demikian, hipotesis penelitian yang menyatakan bahwa hasil belajar TIK siswa dengan sikap kemandirian tinggi jika diajar menggunakan strategi pembelajaran berbasis Internet lebih tinggi dibandingkan dengan siswa yang memiliki sikap kemandirian rendah yang diajar dengan menggunakan strategi pembelajaran ekspositori teruji kebenarannya.

f. Dari hasil perhitungan dengan menggunakan uji Scheffe' pada tabel di atas menunjukkan $\mathrm{F}_{\text {hitung }}=4,58>\mathrm{F}_{\text {tabel }}=$ 2,73, sehingga memberikan keputusan menolak hipotesis nol (Ho), dan hipotesis alternatif (Ha) diterima. Dengan demikian, hipotesis penelitian yang menyatakan bahwa hasil belajar TIK siswa yang memiliki tingkat sikap kemandirian rendah, lebih tinggi jika menggunakan strategi pembelajaran Ekspositori dibandingkan dengan strategi pembelajaran berbasis Internet dengan sikap kemandirian rendah teruji kebenarannya.

Untuk melihat dengan jelas model Anava yang menunjukkan interaksi antara strategi pembelajaran dan Sikap Kemandirian siswa, dapat dilihat pada Gambar 1 berikut. 


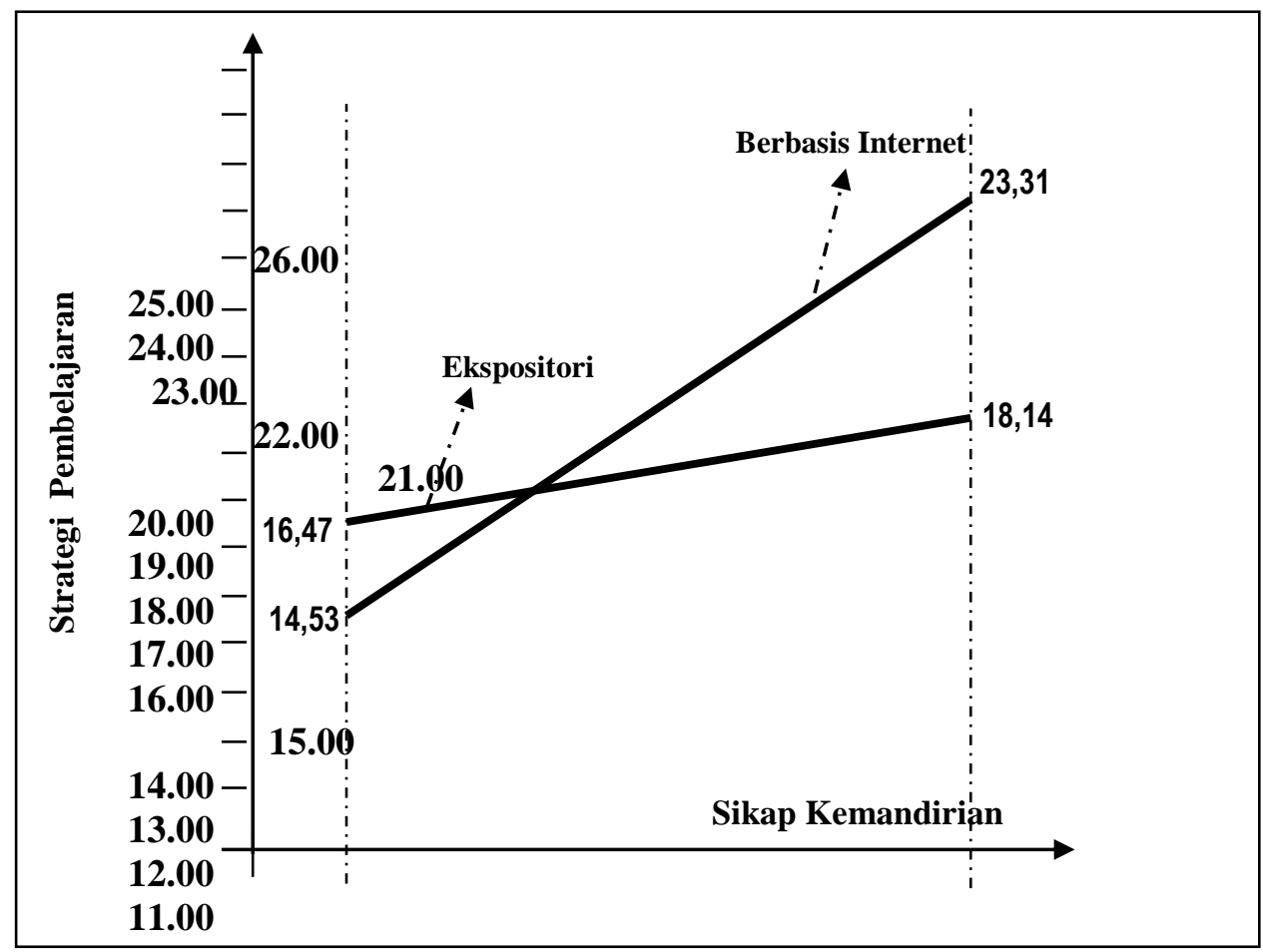

SKR

SKT

Gambar 1. Model interaksi antara strategi pembelajaran dan sikap kemandirian siswa terhadap hasil belajar TIK

\section{Pembahasan}

Strategi pembelajaran berbasis internet merupakan strategi pembelajaran yang berorientasi siswa (student oriented), sehingga dalam pembelajaran berbasis internet, guru berperan sebagai pengarah, pembimbing dan mengelola kelas, sebagai sebuah tim yang bekerjasama untuk menemukan sesuatu yang baru bagi anggota kelas atau siswa serta bertugas membantu siswa untuk mencapai tujuannya. Hal senada disampaikan oleh Robby (2005) bahwa dalam pembelajaran berorientasi siswa Guru lebih banyak berurusan dengan strategi daripada memberi informasi, artinya strategi ini akan memberdayakan dan mendorong siswa untuk terlibat secara aktif dalam mengkonstruk sendiri konsep, pengetahuan dan keterampilan yang ingin dibutuhkannya, sehingga konsep, pengetahuan dan keterampilan tersebut dapat tertanam dalam benak dan ingatan siswa dalam jangka waktu yang lebih lama. Selanjutnya, Evi (2005) mengemukakan bahwa pembelajaran berorientasi siswa akan memberikan kesempatan kepada siswa untuk menemukan sendiri ilmu pengetahuan, informasi dan keterampilan yang dibutuhkan siswa, dimana guru berperan sebagai pengarah, pembimbing dan mengelola kelas, sebagai sebuah tim yang bekerjasama untuk menemukan sesuatu yang baru bagi anggota kelas atau siswa serta bertugas membantu siswa untuk mencapai tujuannya.

Berdasarkan prinsip-prinsip pembelajaran berbasis internet di atas, dapat dipahami bahwa TIK merupakan cabang pengetahuan berkenaan dengan fakta yang tersusun secara sistematis. Penggunaan strategi berbasis internet dirasakan cukup tepat untuk dikembangkan pada bidang studi TIK, sebab manfaat yang dapat diperoleh oleh guru atau pengajar dalam kaitan pembelajaran antara lain : (a) guru dapat lebih mudah melakukan pemutakhiran bahan-bahan belajar yang menjadi tanggung jawabnya sesuai dengan tuntutan perkembangan keilmuan yang terjadi, (b) mengembangkan diri atau melakukan penelitian guna meningkatnya wawasan keilmuan karena waktu dan peluang ralatif banyak, dan (c) melakukan pengecekan tugas-tugas yang diberikan oleh guru terbilang lebih mudah, hingga pengontrolan aktifitas 
penggunaan komputer dapat dilakukan. Pola pembelajaran menggunakan internet seperti ini dapat mengubah peranan guru, yang semula lebih banyak bertindak sebagai satu sumber belajar utama, menjadi pengelola kegiatan belajar yang memberi kesempatan dan bimbingan kepada anak didiknya untuk mencari dan menggunakan sumber belajar lain, sehingga dengan demikian tujuan instruksional yang ditetapkan dapat tercapai.

Sukanto (2006), mengemukakan bahwa strategi pembelajaran berbasis internet dalam pembelajaran dapat meningkatkan efisiensi perolehan pengetahuan baru dengan mengaitkan semua pengetahuan baru dengan struktur kognitif yang sudah ada sebelumnya dalam diri siswa yang belajar. Strategi pembelajaran berbasis internet dapat memudahkan penyandian dan penyimpanan informasi dengan jalan mengorganisasikan pembelajaran dengan cara tertentu sehingga sejalan dengan proses ingatan. Hal terpenting yang dapat dipetik dari penggunaan pembelajaran berbasis internet bahwa berbasis internet akan mampu meningkatkan pemahaman siswa dalam belajar, sebab pembelajaran berbasis internet dapat mengaitkan setiap konsep dengan sejumlah konsep yang lainnya.

Sedangkan pelaksanaan strategi pembelajaran ekspositori didominasi oleh guru, di mana guru bertugas menjalankan pokok-pokok materi dalam waktu yang terbatas, memberi informasi yang kemudian diselingi dengan metode diskusi, latihan mengerjakan soal, dan diselingi dengan penjelasan dari guru secara klasikal atau kelompok sewaktu siswa lain mengerjakan tugasnya. Hal senada dikemukakan oleh Makhyar (2005), bahwa dalam strategi pembelajaran ekspositori, pembelajaran mata pelajaran TIK dianggap kurang efektif. Hal ini disebabkan dalam pada strategi pembelajaran ekspositori materi ajarnya disusun paling tidak hanya memuat hal-hal sebagai berikut: (1) penetapan topik ajaran; (2) pemilahan materi ajar ke dalam sub topik; (3) uraian materi ajar, (4) penyajian catatan penting dari sub topic, (5) penyajian contoh-contoh soal, dan (6) pemberian soal soal latihan. Selain itu, pada pembelajaran ekspositori, materi ajar TIK biasanya disusun tanpa memperhatikan teori-teori instruksional yang didahului dengan analisis karakteristik siswa dan karakteristik mata pelajaran.
Selanjutnya, pada pembelajaran ekspositori, proses pembelajaran lebih berorientasi pada guru, artinya guru merupakan satu-satunya sumber informasi dan pengetahuan siswa (teacher centre). Karena strategi pembelajaran ini berorientasi pada guru dan biasanya ceramah menjadi pilihan utama metode pembelajarannya, maka kondisi pembelajaran seperti ini akan mengakibatkan siswa kurang diberdayakan dalam menemukan ilmu pengetahuan yang dibutuhkannya, sehingga siswa memperoleh ilmu dan pengetahuan tersebut berdasarkan apa yang disampaikan oleh gurunya saja. Sejalan dengan pendapat ini, temuan Nawawi (2004) mengemukakan bahwa model pembelajaran ekspositori merupakan model pembelajaran yang strategi pengorganisasian pembelajarannya menggunakan guru sebagai satu-satunya sumber belajar, artinya guru sebagai pemegang kendali dan kontrol dalam menetapkan isi, metode, dan menilai hasil belajar siswa. Sejalan dengan pendapat di atas, Agustanto (2008) mengemukakan bahwa strategi pembelajaran ekspositori tersebut tidak mendorong tumbuhnya rasa keingintahuan dan rasa tanggung jawab siswa dalam merencanakan dan mengorganisasikan cara belajarnya. Akibatnya, pengetahuan dan keterampilan yang dimiliki siswa hanya berada pada ingatan jangka pendek saja, dan akan cenderung tidak mampu dalam meningkatkan daya retensi siswa terhadap materi pelajarannya. Dalam pembelajaran tersebut komunikasi yang berlangsung dalam proses pembelajaran satu arah, maka cenderung menimbulkan kesalahpamahaman siswa terhadap konsep-konsep dan istilah tertentu.

Kemandirian adalah suatu sikap individu yang diperoleh secara kumulatif selama perkembangan, individu akan terus belajar untuk bersikap mandiri dalam menghadapi berbagai situasi lingkungan, sehingga individu pada akhirnya akan mampu berfikir dan bertindak sendiri dengan kemandiriannya seseorang dapat memilih jalan hidupnya untuk dapat berkembang dengan lebih mantap. Hasil penelitian ini sejalan dengan pendapat Gardner (1983) Siswa yang mandiri dalam belajar adalah siswa mampu dalam mewujudkan kehendak atau keinginannya secara nyata dengan tidak bergantung pada orang lain, dalam hal ini adalah siswa tersebut mampu melakukan belajar sendiri, dapat menentukan cara belajar 
yang efektif, mampu melaksanakan tugastugas belajar dengan baik dan mampu untuk melakukan aktivitas belajar secara mandiri.

Dari deskripsi di atas, dapat dipahami bahwa siswa dengan kemandirian yang tinggi akan mampu memahami materi pelajaran TIK dengan lebih baik. Siswa yang memiliki kemandirian dapat menangkap dan memaknai esensi yang terkandung dalam pembelajaran tertentu, sebab Siswa yang memiliki kemandirian tinggi memiliki ciri-ciri, antara lain: (a) mampu berfikir secara kritis, kreatif dan inovatif, (b) tidak mudah terpengaruh oleh pendapat orang lain, (c) tidak lari atau menghindari masalah, (d) memecahkan masalah dengan berfikir yang mendalam, (e) apabila menjumpai masalah dipecahkan sendiri tanpa meminta bantuan orang lain, (f) tidak merasa rendah diri apabila harus berbeda dengan orang lain, (g) berusaha bekerja dengan penuh ketekunan dan kedisiplinan, dan (h) bertanggung jawab atas tindakannya sendiri.

Hasil penelitian di atas sejalan dengan pendapat Jones (1983) Siswa yang memiliki kemandirian tinggi bertindak dan melakukan aktivitas belajar yang di dorong oleh kemauan sendiri, pilihan sendiri dan tanggung jawab sendiri tanpa bantuan orang lain serta mampu mempertanggungjawabkan tindakannya. Siswa dengan kemandirian tinggi mampu melakukan tugas belajar tanpa ketergantungan dengan orang lain, memiliki kemahiran dalam menyelesaikan tugas belajarnya dan mampu mengimplementasikan pengetahuan yang diperolehnya tersebut.

Hal senada dikemukakan oleh Usmaidar (2007), bahwa siswa dengan kemandirian rendah, kurang memiliki kemampuan atau keterampilan untuk mengungkapkan makna yang terkandung dalam suatu materi pelajaran atau kurang mampu menyimbolkan informasi secara visual. Siswa yang memiliki kemandirian rendah kurang memiliki percaya diri, sehingga cenderung mengalami kesulitan dalam menjawab dan memenuhi kebutuhan belajarnya. Rasa kurang percaya diri tersebut akan mengakibatkan ketidakmampuan siswa bekerja sendiri, sehingga dengan sendirinya siswa akan merasa kesulitan dalam menguasai keahlian dan ketrampilan yang sesuai dengan kerjanya, dan selanjutnya siswa tersebut kurang bertanggung jawab terhadap tugas yang dibebankan padanya secara mandiri dan senantiasa bergantung pada orang lain.
Selanjutnya, McKim mengemukakan, siswa dengan kemandirian rendah akan mengalami kesulitan dalam meningkatkan hasil belajarnya, sebab siswa yang memiliki kemandirian rendah cenderung kurang mampu atau lambat untuk beradaptasi dalam menyesuaikan apa-apa yang diketahui dengan apa-apa yang akan dipelajarinya. Dengan kata lain, siswa dengan kemandirian rendah tidak memiliki bekal atau wawasan ilmu yang memadai, sehingga dengan sendirinya siswa tersebut akan mengalami kesulitan untuk memperoleh ilmu dan pengetahuan selanjutnya. Hal tersebut disebabkan siswa dengan kemandirian rendah tidak mampu mengaitkan dan tidak mampu mengidentifikasi keterampilan dasar yang telah dimiliki dengan pengetahuan baru yang dibutuhkannya, sehingga siswa pasif dalam menerima materi dan menyelesaikan soalsoal, karena tidak mampu memberikan kontribusi dan ide yang berarti dalam proses pembelajaran.

Terdapat interaksi antara strategi pembelajaran dan kemandirian dalam mempengaruhi hasil belajar TIK Siswa. Hasil penelitian ini telah menunjukkan bahwa terdapat interaksi antara strategi pembelajaran dan kemandirian dalam mempengaruhi hasil belajar TIK siswa. Dalam proses belajar, siswa akan mendapatkan perubahan dalam dirinya baik dalam hal kognitif, afektif, dan psikomotorik. Siswa dikatakan berhasil dalam belajar, jika dalam dirinya sudah terjadi perubahan pada ke tiga hal pokok tersebut, sebab belajar merupakan proses aktivitas mental yang berlangsung secara bertahap dan terarah kepada tujuan tertentu, sehingga menghasilkan perubahan yang relatif permanen yang disebabkan latihan dan pengalaman. Selanjutnya, tujuan pendidikan adalah bagaimana usaha untuk mewujudkan suasana belajar dan proses pembelajaran agar peserta didik secara aktif mengembangkan potensi dirinya sesuai dengan kebutuhan pribadinya dan masyarakat. Untuk memenuhi hal tersebut, guru harus dapat mengelola proses pembelajaran itu sehingga dapat membangkitkan kemandirian siswa, agar siswa memiliki sifat selalu ingin tahu, memiliki minat yang luas, dan memiliki aktivitas yang kreatif.

Untuk siswa yang memiliki kemandirian tinggi, memperoleh hasil belajar TIK yang lebih tinggi jika dibelajarkan dengan strategi pembelajaran berbasis internet 
dari pada strategi pembelajaran ekspositori. Pembelajaran berbasis internet merupakan pembelajaran yang bermanfaat dalam; (a) memberikan siswa potensi perkembangan teknologi komputer, sehingga siswa dapat berkreatifitas dan termotivasi untuk mengevaluasi dan mempelajari teknologi tersebut, dan (b) memotivasi kemampuan siswa untuk bisa beradaptasi dan mengantisipasi perkembangan teknologi internet sehingga siswa bisa melakukan dan menjalani aktivitas kehidupan sehari-hari secara mandiri dan lebih percaya diri. Dengan demikian, untuk mewujudkan manfaat di atas, dibutuhkan siswa yang mampu untuk mengajukan bermacam pendekatan dan alternatif pemecahan masalah dari berbagai tinjauan, sebab pembelajaran berbasis internet mengutamakan pengalaman nyata, berpikir tingkat tinggi dan berorientasi pada siswa yang aktif, kritis dan kreatif. Pembelajaran berbasis internet menuntut siswa untuk mampu melahirkan gagasan-gagasan asli sebagai hasil pemikiran sendiri (originality), sehingga kegiatan untuk menemukan sendiri pengetahuan dan keterampilan yang dibutuhkan (inquiry), serta dapat membangun sendiri lingkungan belajarnya (konstructivism).

Pembelajaran berbasis internet akan lebih bermakna bagi siswa dengan kemandirian tinggi, karena proses pembelajaran akan berlangsung dalam bentuk kegiatan bekerja dan mengalami, bukan transfer pengetahuan dari guru ke siswa. Untuk pembelajaran berbasis internet dibutuhkan kemandirian tinggi guna menguraikan sesuatu hal secara terperinci, selalu terdorong untuk tahu lebih banyak tentang sesuatu, merasa tertantang untuk menghadapi situasi yang sulit dan berupaya secara aktif untuk mengatasi soal-soal yang diberikan untuk memperoleh hasil belajar TIK yang lebih baik sesuai dengan tujuan instruksional yang telah ditetapkan. Siswa dengan kemandirian tinggi jika dibelajarkan dengan strategi pembelajaran berbasis internet akan mampu berpikir secara logis dan rasional dalam menyelesaikan soal-soal secara rinci, terurut, dan menggunakan langkah-langkah penyelesaian soal secara sistematis, karena mampu mengaitkan antara materi yang sudah dikuasai dengan materi yang akan dipelajari olehnya.

Bagi siswa yang memiliki kemandirian rendah jika diajarkan dengan strategi pembelajaran berbasis internet akan mengalami kesulitan untuk membangun atau mengkonstruk pengetahuan dan keterampilan TIK yang dibutuhkannya, sebab siswa dengan kemandirian rendah memiliki tingkat kecepatan yang rendah dalam memahami, dan memaknai materi-materi esensial pelajaran TIK. Struktur kognitif siswa dengan kemandirian rendah membutuhkan waktu dan proses pembelajaran yang lebih lama untuk mencerna suatu materi pelajaran TIK yang disajikan. Hal senada dikemukakan oleh Sutrisno (2006) bahwa pembelajaran berbasis internet menuntut kemampuan dalam menyelesajkan soal-soal secara rinci, terurut, dan sistematis. Hal tersebut tidak mampu dilakukan oleh siswa dengan kemandirian rendah, sebab struktur kognitif siswa dengan kemandirian rendah membutuhkan waktu dan proses pembelajaran yang lebih lama untuk mencerna suatu materi pelajaran TIK yang baru. Siswa dengan kemandirian rendah akan mengalami kesulitan-kesulitan dalam menyelesaikan soal-soal TIK yang dihadapinya, karena pengetahuan dan keterampilan yang dimilikinya berdasarkan informasi yang diberitahukan oleh gurunya bukan karena ditemukan sendiri olehnya, dengan kata lain proses pembelajaran adalah transfer pengetahuan dari guru ke siswa. Strategi pembelajaran seperti ini adalah bentuk pembelajaran di mana kelas masih berfokus pada guru sebagai sumber utama pengetahuan, kemudian ceramah menjadi alternatif utama strategi pembelajaran. Di samping itu, pengetahuan hanya dianggap sebagai seperangkat fakta-fakta yang harus dihafal.

Sebaliknya, untuk siswa yang memiliki kemandirian rendah, jika diajar dengan strategi pembelajaran ekspositori akan memperoleh hasil belajar yang lebih baik, sebab strategi pembelajaran ekspositori adalah suatu strategi pembelajaran yang berpusat pada guru (teacher centred). Artinya, proses pembelajaran didominasi oleh guru, di mana guru berperan sebagai narasumber dan merangsang siswa untuk mengeluarkan ideide atau konsep dengan pertanyaanpertanyaan yang mudah dipahami dalam memecahkan masalah. Di akhir pembelajaran, dilakukan kegiatan tanya jawab, memberikan tugas kepada siswa untuk membuat rangkuman pelajaran yang baru diikuti dibuku catatan masing-masing dengan memberitahukan terlebih dahulu materi- 
materi penting pada pembelajaran yang baru dilakukan. Hasil penelitian ini mendukung pendapat Suparman (1997) yang mengemukakan bahwa pembelajaran ekspositori menempatkan guru sebagai satusatunya sumber belajar, dan juga pendapat Nawawi (2004) yang mengatakan bahwa model pembelajaran ekspositori merupakan model pembelajaran yang strategi pembelajarannya menggunakan pembelajar sebagai satu-satunya sumber belajar.

\section{PENUTUP}

\section{Simpulan}

1. Hasil belajar TIK yang dibelajarkan dengan strategi pembelajaran berbasis internet lebih tinggi dibandingkan dengan jika dibelajarkan dengan menggunakan strategi pembelajaran ekspositori.

2. Siswa yang memiliki kemandirian tinggi memperoleh hasil belajar TIK yang lebih tinggi dibandingkan dengan siswa yang memiliki kemandirian rendah.

3. Terdapat interaksi antara strategi pembelajaran dan kemandirian dalam mempengaruhi hasil belajar TIK. Untuk siswa yang memiliki kemandirian tinggi lebih efektif dalam meningkatkan hasil belajar TIK siswa menggunakan strategi pembelajaran elaborasi, sedangkan untuk siswa yang memiliki tingkat kemandirian rendah, ternyata strategi pembelajaran ekspositori lebih efektif dalam meningkatkan hasil belajar TIK siswa dibandingkan jika menggunakan strategi pembelajaran berbasis internet.

\section{Saran}

1. Mengupayakan mutu pendidikan dapat dikembangkan melalui proses pembelajaran yang bervariasi. Salah satu alternatif pengembangannya adalah melalui pemilihan strategi pembelajaran yang tepat dengan tujuan pembelajaran, materi pembelajaran, kemampuan, kondisi dan karakteristik siswa. Strategi yang dapat dipilih antara lain adalah strategi pembelajaran berbasis internet dan strategi pembelajaran ekspositori..

2. Diharapkan kepada para guru TIK atau tenaga pengajar umumnya agar senantiasa memperhatikan dan mempertimbangkan faktor kemandirian siswa sebagai pijakan dalam merancang pembelajaran, sebab kemandirian merupakan kekuatan dan kemampuan dalam melakukan sesuatu tanpa tergantung orang lain, baik dalam merencanakan, mengelola dan menyelesaikan kegiatan belajarnya.

3. Guru perlu memiliki pemahaman dan wawasan yang baik tentang strategi pembelajaran berbasis internet, sehingga strategi pembelajaran ini dapat dijadikan menjadi salah satu strategi pembelajaran untuk mengoptimalkan hasil belajar TIK siswa dengan kemandirian tinggi maupun kemandirian rendah.

\section{DAFTAR PUSTAKA}

Ali, Mohammad. (2004). Modul Kiat Mengembangkan Sikap Mandiri. Universitas Pendidikan Indonesia.

Atmadi, A. (2000). Transformasi Pendidikan Memasuki Millenium Ketiga. Yogyakarta : Kanisius.

Bloom, Benyamin. (1982). Human Characteristics and School Learning. New York : Mc. Grow Hill Book Company.

Dabbagh Nada, Ritland Bannan Brenda. (2005) Online Learning : Concepts. Strategies, and Aplication. New Jersey : Pearson Prentice Hall.

Departemen Pendidikan Nasional. (2003) Kurikulum Teknologi Informasi dan Komunikasi (TIK). Jakarta : Departemen Pendidikan Nasional.

Dick and Carey. (2005). The Sistematic Design of Instruction. Illion : Scott Foresman \& Co.

Dimyati \& Mudjiono (2006). Belajar dan Pembelajaran. Jakarta : Asdi Mahasatya

Djamarah, Syaiful Bahri. (2002). Strategi Belajar Mengajar. Jakarta:Rineka Cipta.

Efendy, Empy dan Zhuang, Hartono. (2005). E-Learning : Konsep dan Aplikasi (ed.1) Yogyakarta : Andi

Ewing K, Levine J, Reinhold A., Margaret L. Y., Lowe D., Harvey G., Mohva V., Kaufeld J., Kufeld J ., Waperka P., Hill 
B., Musick L., (2002). The Internet AllIn One Desk Refence for Dummies. Hungry Minds, Inc.

Gagne, R.M. (1977). The Condition of Learning $3^{\text {rd }}$ edition. New York: Holt Rinehart and Winston Inc.

Gagne, R.M. (1985). Principles of Instructional Design. New York : Holt Rinehart and Winston.

Heinich, RE. (1996). Instructional Media and Technologies for Learning $5^{\text {th }}$. New Jersey : Enggle Wood Prentice Hall

Hurlock, E.B. (1999). Psikologi Perkembangan (Suatu Pendekatan Sepanjang Rentang Kehidupan). Alih Bahasa oleh Istiwidayati \& Zarkasih. Jakarta: Erlangga

Joyce, Bruce \& Weil, Marsha, (1986). Models of Teaching. New Jersey: Prentice Hall Inc.

Masrun, dkk. (1986). Studi Mengenai Kemandirian pada Penduduk di Tiga Suku Bangsa ( Jawa, Batak, Bugis). Laporan Penelitian. Yogyakarta: Fakultas Psikologi UGM.

Merrill, MD. (1977). A Lesson Based on The Component Display Theory" Instruction Theories in Action. New Jersey : Lawrence Erlbaum Ass.

Miarso, Yusuf Hadi. (2005). Menyemai Benih Teknologi Pendidikan. Jakarta : Kencana.

Mussen, P.H; Conger, J.J; Kagan, J; Huston, A.C. (1989). Perkembangan dan Kepribadian Anak. Edisi Keenam. Diterjemahkan Oleh F.X. Budianto, Gianto Widianto dan Arum Gayatri. Cetakan II. Jakarta: Penerbit Arcan.

Mu'tadin. (2002). Aspek-aspek kemandirian. (Materi pembelajaran online) (www.e_psikologi.com, diakses $12 \mathrm{Juli}$ 2002).

Piaget, J. (1970). Science of Education and the psychology of the child. New York : Wiley.
Reigeluth, Charles, M. (1983). Instructional Design Theories and Models: An Overview of Their Current Status. New Jersey: Lawrence Erlbaum Associates.

Romizowski, A.J. (1981). Designing Instructional System. New York : Nicholas Publishing.

Rosenberg, J.M., (2001). E-learning: Strategies for delivering knowledge in the digital age, USA : MeGraw-Hill.

Rusman. (2007). Konsep Dasar Teknologi Informasi dan Komunikasi, Perkembangan dan Pemanfaatan Komputer. (Materi pembelajaran online) unit 1 dan 2 (www.umm.ac.id/pji/file.php/1/moddat a/forum/1/15/, diakses 7 September (2007).

Salisbury David F. (1996). Five Technologies for Educational Change : system thinking, system design, quality science, change management, instructional technology. USA : Englewood Cliffs, New Jersey.

Sanjaya, Wina. (2006). Strategi Pembelajaran. Jakarta : Prenada Media Group.

Santrock, J.W. (1999). Life Span Development. Seventh Edition. New York: The McGraw-Hill Companies.

Snelbecker, Glen E., (1974). Learning Theory and Instructional, Theory and Psychoeducational Design., New York : Mc-Graw Hill Inc Company.

Soedjadi, R. (1995). Pendidikan, Penalaran, Konstruktivisme, Kreativitas Sajian dalam Pembelajaran Matematika. PPs IKIP Surabaya.

Steinberg, L. (2002). Adolescence. Sixth edition. New York: McGraw-Hill.

Surya, Muhamad. (2006). Potensi Teknologi Informasi dan Komunikasi Dalam 
Peningkatan Mutu Pembelajaran di Kelas, (www.edukasi.net/artikel diakses 5 September 2006)
Undang-Undang Republik Indonesia No. 20 Tahun (2003). Tentang Sistem Pendidikan Nasional. Jakarta : Eka Jaya. 